\title{
Increased bone mineral content of preterm infants fed with a nutrient enriched formula after discharge from hospital
}

\author{
N J Bishop, F J King, A Lucas
}

\begin{abstract}
Bone disease with persistent reduced bone mineralisation is common in premature infants. To test the hypothesis that enhancement of nutritional intake after discharge from hospital improves bone mineralisation, 31 formula fed preterm infants were randomly assigned to receive standard or multinutrient enriched milk from the time of discharge. The calcium and phosphorus contents of the enriched milk were 70 and $35 \mathrm{mg} / 100 \mathrm{ml} v 35$ and 29 $\mathrm{mg} / 100 \mathrm{ml}$ for the standard formula. Bone mineral content was measured before discharge from hospital in 21 of the infants; there was no difference in the bone mineral content between the groups at that time (35 mg/cm for the two groups). There was a significant increase in bone mineral content for those infants receiving the enriched $v$ standard formula at 3 and 9 months corrected postnatal age: at 3 months the bone mineral content was 83 $v 63 \mathrm{mg} / \mathrm{cm}$ and at 9 months $115 v 95$ $\mathrm{mg} / \mathrm{cm}$. The difference between the groups was thus maintained although not increased at a corrected age of 9 months, when the bone mineral content of infants fed the enriched but not the standard formula was no longer significantly different from that of normal infants after adjusting for body size. The difference was not explained by the larger body size in infants fed the enriched formula. The results suggest that the use of a special nutrient enriched postdischarge formula has a significant positive effect on bone growth and mineralisation during a period of rapid skeletal development. (Arch Dis Child 1993; 68: 573-578)
\end{abstract}

Bone disease, characterised by disturbances in mineral metabolism, ${ }^{1-3}$ increased plasma alkaline phosphatase activity, ${ }^{4}$ reduced bone mineralisation, ${ }^{56}$ and abnormal bone remodelling ${ }^{7}$ with reduced growth velocity ${ }^{4}$ has been widely reported for preterm infants. Dietary insufficiency, particularly of the bone minerals calcium and phosphorus, has been identified as a significant aetiological factor, ${ }^{8-10}$ and studies using mineral supplemented formulas during the period in hospital have shown that in utero accretion rates for bone minerals can be achieved in well preterm infants fed by mouth. ${ }^{1-13}$ Nevertheless, many preterm infants still leave hospital retarded in growth, and with under mineralised bones. This study was undertaken to test the hypothesis that prolonged nutritional supplementation after discharge from hospital using a formula specifically enriched in the key ingredients likely to enhance bone development (protein, energy, calcium, and phosphorus) would result in improved bone mineralisation up to a corrected postnatal age of 9 months in formula fed infants born preterm.

\section{Subjects and methods}

We recruited 31 preterm infants before discharge home from the neonatal intensive care unit. Inclusion criteria included weight less than $1850 \mathrm{~g}$ at birth and less than $300 \mathrm{~g}$ at entry to the study, age less than 100 days at discharge, freedom from major congenital malformations and diseases likely to influence growth and development, and formula rather than human milk fed during their stay in hospital. Ethical approval for the study was given by the Cambridge Health Authority and the Medical Research Council Dunn Nutrition Unit ethics committees.

Infants were randomised, after informed parental consent, to receive either a standard term formula (Farley's Ostermilk, Crookes Health Care), or a specially designed 'follow on preterm formula' (Farley's Premcare, manufactured to our specifications by Crookes Health Care). Full compositional details have been published previously ${ }^{14}$; potentially relevant differences are shown in table 1 . The largest difference (in percentage terms) is in the mineral content of the two milks, but protein and energy are also increased in the enriched formula.

The randomisation was stratified by sex. The infants had all been in the neonatal intensive care unit of the Rosie Maternity Hospital, Cambridge before randomisation, and had had extensive data collection undertaken from birth. The infants were fed with the formula milk while still in hospital. They were visited at home fortnightly by a research nursing sister

Table 1 Key nutrients (per $100 \mathrm{ml}$ ) in standard and enriched formula milks

\begin{tabular}{|c|c|c|}
\hline Factor & $\begin{array}{l}\text { Standard } \\
\text { formula }\end{array}$ & $\begin{array}{l}\text { Enriched } \\
\text { formula }\end{array}$ \\
\hline $\begin{array}{l}\text { Energy (kcal) } \\
\text { Protein (g) } \\
\text { Calcium (mg) } \\
\text { Phosphorus (mg) } \\
\text { Magnesium (mg) } \\
\text { Vitamin D ( } \mu \mathrm{g})\end{array}$ & $\begin{array}{l}67 \\
1 \cdot 45 \\
35 \\
29 \\
5 \cdot 2 \\
1 \cdot 0\end{array}$ & $\begin{array}{l}72 \\
1 \cdot 85 \\
70 \\
35 \\
5 \cdot 2 \\
1 \cdot 2\end{array}$ \\
\hline
\end{tabular}

$\star^{\star} 1 \mathrm{kcal}=4 \cdot 18 \mathrm{~kJ}$ 
Table 2 Demographic data for the infants divided by diet after discharge. Results given as mean $(S D)$ unless stated otherwise

\begin{tabular}{|c|c|c|}
\hline & $\begin{array}{l}\text { Standard } \\
\text { formula } \\
(n=15)\end{array}$ & $\begin{array}{l}\text { Enriched } \\
\text { formula } \\
(n=16)\end{array}$ \\
\hline $\begin{array}{l}\text { Gestation (weeks) } \\
\text { Birth weight (g) } \\
\text { Boys:girls } \\
\text { No of infants ventilated }\end{array}$ & $\begin{array}{c}31 \cdot 7(1 \cdot 9) \\
1436(227) \\
8: 7\end{array}$ & $\begin{array}{c}30 \cdot 7(1 \cdot 7) \\
1513(173) \\
7: 9\end{array}$ \\
\hline $\begin{array}{l}\text { No of infants ventilated } \\
>1 \text { day }\end{array}$ & & \\
\hline $\begin{array}{l}>1 \text { day } \\
>7 \text { days }\end{array}$ & $\begin{array}{l}6 \\
0\end{array}$ & \\
\hline $\begin{array}{l}\text { No of days in intravenous feeding (median, interquartile range) } \\
\text { Postmenstrual age at trial entry (weeks) }\end{array}$ & $\begin{array}{l}4(2-8) \\
37(2)\end{array}$ & $\begin{array}{l}5(3-10) \\
37(2)\end{array}$ \\
\hline $\begin{array}{l}\text { Feed volume }(1) \\
0-3 \text { months } \\
>3-6 \text { months } \\
>6-9 \text { months }\end{array}$ & $\begin{array}{l}73 \cdot 4(13 \cdot 5) \\
69 \cdot 4(15 \cdot 4) \\
75 \cdot 1(32 \cdot 0)\end{array}$ & $\begin{array}{l}71.6(14.9) \\
69.8(12 \cdot 2) \\
65.6(23.9)\end{array}$ \\
\hline
\end{tabular}

Table 3 Anthropometric data at trial entry and at corrected postnatal ages of 3 and 9 months grouped by dietary assignment. Results given as mean (SD)

\begin{tabular}{|c|c|c|}
\hline & $\begin{array}{l}\text { Standard } \\
\text { formula } \\
(n=15)\end{array}$ & $\begin{array}{l}\text { Enriched } \\
\text { formula } \\
(n=16)\end{array}$ \\
\hline \multicolumn{3}{|l|}{ Trial entry } \\
\hline Weight (g) & $2383(221)$ & $2401(343)$ \\
\hline Length $(\mathrm{cm})$ & $46(0 \cdot 14)$ & $46.3(0.22)$ \\
\hline Head circumference $(\mathrm{cm})$ & $33 \cdot 3(0 \cdot 10)$ & $33 \cdot 2(0.12)$ \\
\hline \multicolumn{3}{|l|}{ Three months } \\
\hline Weight (g) & $5531(223)$ & $5819(200)$ \\
\hline Length $(\mathrm{cm})$ & $58.9(0.61)$ & $60.4(0.49)$ \\
\hline Head circumference $(\mathrm{cm})$ & $40.9(0.37)$ & $41.5(0.41)$ \\
\hline \multicolumn{3}{|l|}{ Nine months } \\
\hline Weight (g) & $7584(400)$ & $8208(389)$ \\
\hline Length $(\mathrm{cm})$ & $69 \cdot 6(0 \cdot 81)$ & $70.7(0.94)$ \\
\hline Head circumference $(\mathrm{cm})$ & $45.3(0.31)$ & $45.8(0.55)$ \\
\hline
\end{tabular}

(FJK) who recorded anthropometric and clinical details. Length was measured to the next succeeding $1 \mathrm{~mm}$ using a horizontal stadiometer and weight to the nearest $10 \mathrm{~g}$ using Sartorius electronic balance scales. Every two weeks supplies of milk were delivered to the home in preweighed crates of ready-to-feed bottles. The mother was instructed to use a teat directly on the bottle during a feed, and afterwards to remove the teat, recap the empty or partially empty bottle, and replace it in the crate. At the end of each two week period the entire crate was reweighed. The volume intake of formula milk was calculated as the difference in the weight of the crate at the beginning and end of the two week period. The infants received the assigned diet, either alone or in conjunction with other foods, after weaning, up to a corrected postnatal age of 9 months.

Measurement of bone width and mineral content was undertaken using single photon absorptiometry (Lunar SP2, Lunar Radiation). A collimated beam of photons from an iodine125 source passed across the arm to a photomultiplier detector. The source and detector moved in tandem across the arm, and the bone width and mineral content were calculated from the attenuation of the photon beam. Each infant was placed supine with the left arm extended. The forearm was enfolded in a tissue equivalent bag made from dialysis tubing filled with warm water. With the arm held perpendicular to the beam path, two scans across the forearm were undertaken along the same track. Where the difference between scans exceeded $5 \%$ the scan was repeated. The surface radiation dose for each scan would be $20 \mu \mathrm{Sv}$ with a new source, ${ }^{15}$ approximately $10 \%$ of that from a forearm radiograph, and well within the fluctuations of normal daily background radiation.

Measurements were undertaken at the one third distal site - that is, the position corresponding to one third of the distance from the tip of the olecranon to the ulnar styloid process, measured distally from the styloid process. The radius at this point approximates a cylinder over a two to three centimetre distance and thus provides a geometrically stable measuring area. Twenty of the 31 infants studied had their bone width and mineral content measured before discharge from hospital; the remainder had returned to peripheral referring units before such a measurement could be made. All infants returned to our unit for measurements at corrected postnatal ages of 3 and 9 months.

The analysis of results was restricted initially to those infants for whom a baseline measurement of bone mineral content had been performed. These were then compared with the results obtained when the complete groups were analysed.

All infants were included in the regression analyses; the results from the initial group comparisons suggest that it is appropriate to do this, and in addition it was thought unlikely that the measurement of bone mineral content in hospital would of itself influence later bone growth or mineralisation.

All the analyses were undertaken using the DataDesk package for the Apple Macintosh computer.

\section{Results}

Tables 2 and 3 show the demographic and anthropometric data at trial entry and corrected ages of 3 and 9 months separated by diet group. The groups were well matched for gestational age, birth weight, and severity of initial respiratory illness. There were no significant differences in body weight, length, head circumference, or skinfold thickness at trial entry. Formula consumption was similar between the two groups. Details for the infants as a combined group have been published previously ${ }^{14}$; table 3 includes a precis of the volume intake on each diet. We have reported previously that the infants receiving the nutrient enriched formula became longer and heavier than those fed the standard term formula. ${ }^{14}$

The radial bone width and mineral content estimations for each group before discharge and at corrected ages of 3 and 9 months are shown in table 4 for the infants measured initially while in hospital. There were significant differences in bone mineral content between the diet groups at both postdischarge time periods (difference in means $(95 \%$ confidence interval) of enriched and standard formula groups 20 (6 to 34 ) $\mathrm{mg} / \mathrm{cm}$, and 27 (13 to 40$) \mathrm{mg} / \mathrm{cm}$ at each age respectively).

For all the infants at corrected ages of 3 and 9 months the results are shown in table 5. The differences in bone mineral content between the diet groups at both discharge time periods 
Table 4 Bone width and mineral content of the radius before discharge from hospital and at 3 and 9 months corrected postnatal age grouped by dietary assignment (data are mean (SD) and $95 \%$ confidence interval of difference of group means); analysis restricted to those infants first measured in hospital

\begin{tabular}{|c|c|c|c|c|}
\hline & $\begin{array}{l}\text { Enriched } \\
\text { formula } \\
(n=11)\end{array}$ & $\begin{array}{l}\text { Standard } \\
\text { formula } \\
(n=9)\end{array}$ & $\begin{array}{l}\text { Difference } \\
\text { of means }\end{array}$ & $\begin{array}{l}95 \% \\
\text { Confidence } \\
\text { interval }\end{array}$ \\
\hline \multicolumn{5}{|l|}{ Bone width (cm) } \\
\hline Before discharge & $0.368(0.043)$ & $0.360(0.030)$ & 0.008 & -0.023 to 0.039 \\
\hline 3 months & $0.603(0.085)$ & $0.562(0.084)$ & 0.041 & -0.039 to 0.121 \\
\hline 9 months & $0.684(0.071)$ & $0.610(0.078)$ & 0.074 & 0.004 to 0.141 \\
\hline \multicolumn{5}{|c|}{ Bone mineral content $(\mathrm{mg} / \mathrm{cm})$} \\
\hline Before discharge & $35 \cdot 1(11 \cdot 6)$ & $34.9(7 \cdot 8)$ & $0 \cdot 2$ & $-7 \cdot 9$ to $8 \cdot 3$ \\
\hline 3 months & $84 \cdot 3(17 \cdot 2)$ & $64 \cdot 0(12 \cdot 6)$ & $20 \cdot 3$ & $6 \cdot 2$ to $34 \cdot 2$ \\
\hline 9 months & $112 \cdot 1(17 \cdot 6)$ & $95 \cdot 3(11 \cdot 1)$ & $26 \cdot 8$ & $13 \cdot 2$ to $40 \cdot 4$ \\
\hline
\end{tabular}

Table 5 Bone width and mineral content of the radius at 3 and 9 months corrected postnatal age grouped by dietary assignment (data are mean (SE) and $95 \%$ confidence interval of difference of group means); all infants

\begin{tabular}{lcccc}
\hline & $\begin{array}{l}\text { Enriched } \\
\text { formula } \\
(n=16)\end{array}$ & $\begin{array}{l}\text { Standard } \\
\text { formula } \\
(n=15)\end{array}$ & $\begin{array}{l}\text { Difference } \\
\text { of means }\end{array}$ & $\begin{array}{l}95 \% \\
\text { Confidence } \\
\text { interval }\end{array}$ \\
\hline $\begin{array}{l}\text { Bone width }(\mathrm{cm}) \\
\quad 3 \text { months }\end{array}$ & $0.581(0.021)$ & $0.565(0.024)$ & 0.016 & -0.046 to 0.078 \\
$\quad \begin{array}{l}\text { 9 months } \\
\text { Bone mineral content }(\mathrm{mg} / \mathrm{cm})\end{array}$ & $0.669(0.022)$ & $0.619(0.022)$ & 0.050 & -0.011 to 0.111 \\
$\quad 3$ months & $83.2(4.5)$ & $62.9(3.6)$ & 20.3 & 9.1 to 31.5 \\
9 months & $115.3(5 \cdot 4)$ & $94.7(3.7)$ & 20.6 & 7.4 to 33.8 \\
\hline
\end{tabular}

were almost identical with those seen for the smaller groups above (difference in mean (95\% confidence interval) bone mineral content of enriched and standard formula groups $20(9$ to 31$) \mathrm{mg} / \mathrm{cm}$ and $21(7$ to $34 \mathrm{mg} / \mathrm{cm})$ at each age respectively.

The figure shows a graphical comparison of the bone mineral content of infants in this study with that of Cambridge infants born at term. ${ }^{16}$ These data show that by 9 months the bone mineral content in infants fed the enriched diet was about two standard errors lower than in normal controls (figure). After adjusting for body size the bone mineral content in the enriched formula group was even closer to that of the normal controls. The adjustment for body size was performed by plotting the mean value for bone mineral con-

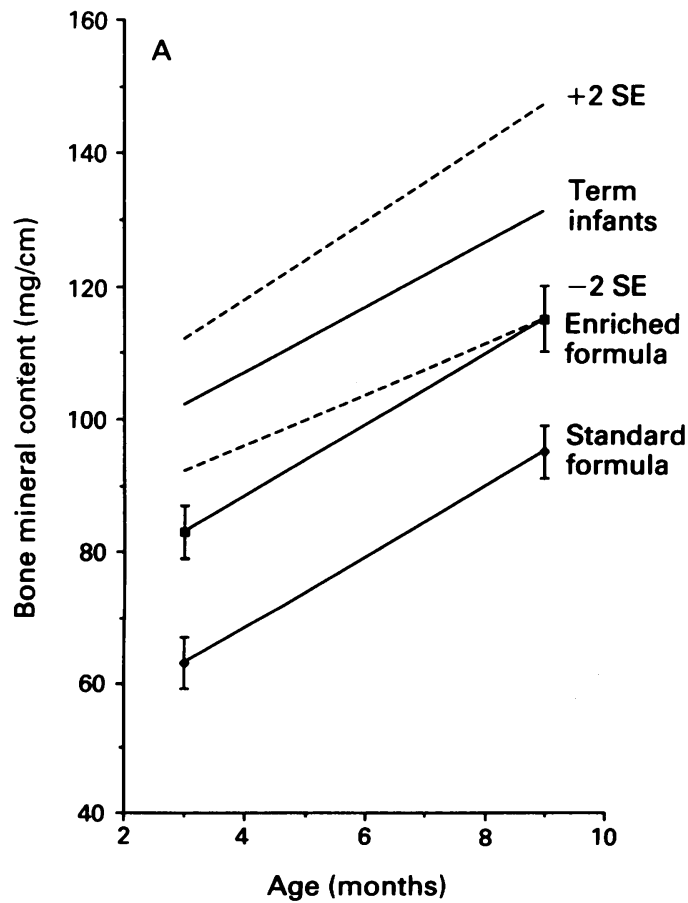

tent at the mean expected age for body weight for each grcup, as weight rather than length was independently associated with the bone mineral content.

We considered that the effect of the enriched formula on mineralisation might be explained by the greater growth rate and body size of infants fed this diet; it would be reasonable to expect that larger infants would have bigger bones and therefore more bone mineral. To explore this, we undertook multiple regression analysis with bone mineral content as the dependent variable and body weight, height, bone width, sex, and diet type (standard or enriched formula) as independent factors.

The diet after discharge was the factor most strongly associated with bone mineral content at 3 months $(t=3 \cdot 85 ; \mathrm{p}<0 \cdot 001)$, exceeding the

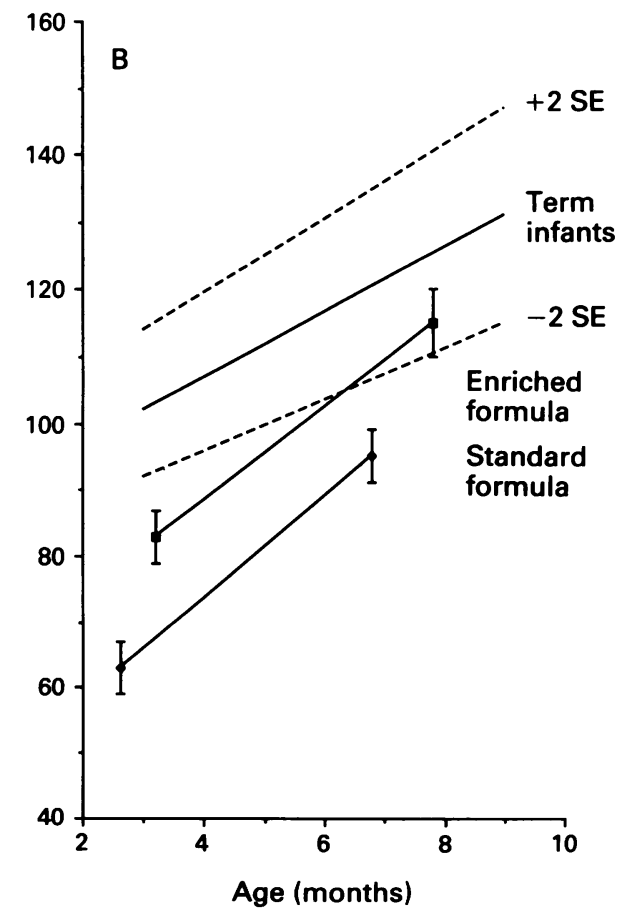

Radial bone mineral content $(\mathrm{mg} / \mathrm{cm}$ ) for preterm infants fed after discharge on standard or enriched formula, compared with reference data from infants born at term. (A) At 3 and 9 months corrected postnatal age; (B) data plotted at ages appropriate to body size. 
Table 6 Regression models of factors influencing bone mineral content $(\mathrm{mg} / \mathrm{cm})$ at corrected postnatal ages of 3 and 9 months

\begin{tabular}{|c|c|c|c|c|}
\hline Factor & $\begin{array}{l}\text { Regression } \\
\text { coefficient }\end{array}$ & $\begin{array}{l}\text { Standard error } \\
\text { coefficient }\end{array}$ & $t$ Value & p Value \\
\hline \multicolumn{5}{|l|}{ Three months } \\
\hline Effect of receiving enriched diet & $16 \cdot 1$ & $4 \cdot 2$ & $3 \cdot 85$ & $0 \cdot 001$ \\
\hline Effect of a unit (g) increase in weight & $0 \cdot 010$ & 0.003 & $3 \cdot 66$ & 0.002 \\
\hline Effect of a unit $(\mathrm{cm})$ increase in bone width & $68 \cdot 3$ & $25 \cdot 8$ & $2 \cdot 65$ & 0.013 \\
\hline \multicolumn{5}{|l|}{ Nine months } \\
\hline Effect of receiving enriched diet & $11 \cdot 8$ & $4 \cdot 9$ & $2 \cdot 40$ & 0.03 \\
\hline Effect of a unit $(\mathrm{cm})$ increase in bone width & $132 \cdot 1$ & $28 \cdot 5$ & 4.63 & 0.0001 \\
\hline Effect of a unit $(\mathrm{g})$ increase in birth weight & 0.027 & 0.012 & $2 \cdot 27$ & 0.03 \\
\hline
\end{tabular}

association with body weight $(t=3.66$; $\mathrm{p}<0.002)$ and with bone width $(t=2.65$; $\mathrm{p}<0.02)$. At 9 months the diet after discharge was still independently associated with bone mineral content $(t=2.62 ; \mathrm{p}<0.03)$, though the effect of bone width was then much stronger $(t=4.59 ; \mathrm{p}<0.0001)$. Thus, our data show that the effect of diet on bone mineralisation was independent of body size and bone width.

It might also be expected that factors in the antenatal and immediate postdelivery period would also influence later bone mineral content. Further multiple regression analysis was undertaken with the bone mineral content at 3 and then at 9 months as the dependent variable. Gestation, birth weight, duration of ventilation (as a marker of the severity of illness), maximum plasma alkaline phosphatase activity, and whether or not the infant was small for gestation (less than the tenth centile) were included as additional independent variables (as well as those in the models above). Diet before discharge was not included in these models as infants in the study were uniformly fed preterm formula until near to discharge.

Table 6 shows the results of stepwise multiple regression models, and lists those factors that had a significant independent relationship with the bone mineral content. For the 3 month data set, diet after discharge (receiving the enriched formula) was the most significant factor, followed by 3 month body weight and bone width. At 9 months the only independent factors were bone width, diet after discharge, and birth weight (in descending order of significance).

To exclude the possibility that in the 3 month model, body weight and bone width (at 3 months) were markers for the infant who was small or sick in the neonatal period, in a further regression analysis we excluded the 3 month weight and bone width. Diet after discharge then remained as the only factor significantly related to the bone mineral content, and there was still no relation between bone mineral content and birth weight, gestation, duration of ventilation, peak neonatal plasma alkaline phosphatase activity, or fetal growth retardation (analysis not shown). No factors could be identified as independently influencing bone width at 3 or 9 months in the complete groups.

For the restricted groups, the velocity of bone mineral accretion from the time of discharge to the measurement made at 3 months corrected age was significantly greater in the infants who received the enriched formula $(192.5 v 112 \mathrm{mg} / \mathrm{cm} /$ year; $t=2 \cdot 14 ; \mathrm{p}<0.05)$; no further divergence between the diet groups was seen over the 3-9 month period, however.

\section{Discussion}

We have shown in a prospective randomised double blind controlled study that preterm infants fed a special nutrient enriched formula as opposed to standard milk formula after discharge from hospital had a higher bone mineral content at 3 and 9 months corrected postnatal age. This effect was independent of body size. After adjusting for a range of antenatal, neonatal, and anthropometric factors, diet after discharge from hospital was the factor which was most strongly related to bone mineral content at an age of 3 months. The difference in mineral accretion velocity was only significantly different between the groups over this first period, but the difference in bone mineral content between the standard and enriched formula fed groups was still maintained at 9 months. By a corrected postnatal age of 9 months the infants receiving the enriched but not the standard formula had a bone mineral content no longer significantly different from that expected for age, after adjusting for body size.

The effect of dietary mineral supplementation on the bone mineralisation in preterm infants during the period in hospital has been studied extensively. A large number of studies support the view that an inadequate intake of bone mineral substrate (rather than vitamin $\mathrm{D}$ deficiency) is the principal factor in the aetiology of bone disease of prematurity..$^{1411-13}$ There have, however, been relatively few studies of the longer term follow up of infants born prematurely in terms of skeletal growth and bone mineralisation. In a previous study of the effect of early diet on later growth and development ${ }^{4}$ we showed that bone disease, as indicated by increased plasma alkaline phosphatase activity, was the factor most strongly associated with reduced body length at 18 months corrected postnatal age, with early diet (formula $v$ unsupplemented human milk) also exerting a substantial independent effect.

Other groups have studied the bone mineral content of preterm infants after discharge from hospital. ${ }^{17-19}$ Congdon et al found a rapid acceleration in the rate of mid-forearm bone mineralisation after discharge from hospital for infants born preterm up to a median corrected age of 10 weeks. ${ }^{17}$ Chan and Mileur found higher values than ours at a corrected postnatal age of 3 months for preterm infants receiving term formula after discharge from hospital ( 95 $\mathrm{mg} / \mathrm{cm}$ ), but the infants' average bone mineral content at discharge was also substantially higher $(52 \mathrm{mg} / \mathrm{cm}) .18$ Schanler et al reported the bone mineral content of infants born preterm at intervals up to 2 years of age. ${ }^{19}$ The infants had received expressed milk from their mothers while in hospital, and then either continued with breast feeding or with a standard term formula according to parental choice after discharge from hospital. The results obtained from that non-randomised study are broadly similar to our own, with the infants receiving the formula milk having a greater bone mineral content at 6 months and 1 year of age than those receiving milk from their mothers. Bone mineralisation was similar in each group at the age of 2 years. 
In this study, infants born at 27-34 weeks' gestation and fed on mineral enriched preterm formula in hospital showed poor bone mineralisation at discharge with a mean value of around $50 \%$ of that expected for their age after conception. Interestingly, we found the infants fed a standard formula after discharge had a markedly decreased bone mineral content even at 9 months after term, when the mean value was only $70 \%$ of that expected for age, and $76 \%$ after adjusting for body size. The corresponding values at 9 months for infants fed the enriched formula were $86 \%$ and $91 \%$.

It was remarkable that at three months after term, the diet after discharge was the only clinical factor identified that related to the bone mineral content. At this age, we found no evidence that infants who were growth retarded at birth or who were more immature, sick, or had a higher peak alkaline phosphatase activity were at risk for developing more poorly mineralised bones. It is possible that such effects were missed because our cohort was relatively small and our selection criteria excluded infants with prolonged respiratory disease. Moreover, before discharge none of the infants were fed with unsupplemented human milk or standard formula which would supply low intakes of bone minerals. Nevertheless, it appears that the nature of the diet after discharge is highly influential for bone mineral accretion in infancy.

In this study the mean stay in hospital was only six weeks (a typical period of hospital stay for a very low birthweight preterm infant). In contrast, our infants received their formula after discharge for an average of 43 weeks. It should not be surprising, therefore, if nutrition policy after discharge proved to be at least as influential as hospital management in terms of later nutritional status.

The bone mineral content estimated by single photon absorptiometry correlates well with total body calcium measured by in vivo neutron activation analysis ${ }^{16}$ and dual energy $x$ ray absorptiometry 20 in adults. Our results therefore suggest an overall increase in the total amount of bone mineral in the skeleton for those infants who received the enriched formula. A number of studies of fractures in childhood have shown that reduced bone mineralisation is a predisposing factor. ${ }^{21-23} \mathrm{We}$ have shown previously that although there was no overall increase in the risk of clinically presenting fractures up to the age of 5 years for infants born prematurely, there was a trend towards earlier presentation (at less than 2 years of age) for those born at less than 33 weeks' gestation. ${ }^{24}$ We speculate that the increased bone mineral content shown here for infants receiving the enriched formula might ameliorate that risk.

Bone mineralisation continues throughout childhood and into adolescence with a more rapid accretion of bone mineral during puberty. ${ }^{25-27}$ Helin et al reported that infants born prematurely had a reduced bone mineral content at follow up to an age of 16 years, but gave no information about early $\operatorname{diet}^{28}$; there are no similar data available for adults born preterm. This raises concern over the potential long term effect on skeletal development of prolonged undermineralisation during the first year of life. It is possible that inadequate provision of dietary calcium and phosphorus during this period when overall growth is normally at its most rapid might affect future bone growth and mineralisation. Clearly, long term follow up of premature infants randomised to different diets in the neonatal period is required to investigate this.

The home use of a multinutrient enriched rather than standard milk formula has improved skeletal growth and bone mineralisation in a group of preterm infants. Previously we reported that these infants, fed the same enriched formula, had improved weight gain and linear growth velocity without impaired feed tolerance. ${ }^{14}$ This group of infants appears to have nutritional requirements which exceed the provisions of the routinely supplied standard term formula. We suggest the use of nutrient enriched postdischarge milk should now be considered for each preterm infant as they leave hospital

1 Sagy M, Birenbaum E, Balin A, Orda S, Barzilay Z, Brish $M$. Phosphate-depletion syndrome in a premature infant fed human milk. $\mathcal{F}$ Pediatr 1980; 96: 683-5.

2 Lyon AJ, McIntosh N, Wheeler K, Brooke OG. Hypercalcaemia in extremely low birthweight infants. Arch Dis Child 1984; 59: 1141-4.

3 Rowe J, Rowe D, Horak E, et al. Hypophosphatemia and hypercalciuria in small premature infants fed human milk: evidence for inadequate dietary phosphorus. $\mathcal{F}$ Pediatr 1984; 104: 112-7.

4 Lucas A, Brooke OG, Baker BA, Bishop N, Morley R. High plasma alkaline phosphatase activity and growth in preterm neonates. Arch Dis Child 1989; 64: 902-9.

5 Greer FR, McCormick A. Bone growth with low bone mineral content in very low birth weight premature infants. Pediatr Res 1986; 20: 925-8.

6 James JR, Congdon PJ, Truscott J, Horsman A, Arthur R.

7 Osteopenia of prematurity. Arch Dis Child 1986; 61: 871-6. S. Skeletal changes in preterm infants. Arch Dis Child 1982; 157: 447-52.

8 Greer FR, Tsang RC. Calcium phosphorus magnesium and vitamin $D$ requirements for the preterm infants. In: Tsand $\mathrm{RC}$, ed. Vitamin and mineral requirements in preterm infants. New York: Marcel Dekker, 1985: 99-136.

9 Steichen JJ, Gratton TL, Tsang RC. Osteopenia of prematurity: the cause and possible treatment. $f$ Pediat 1980; 3: 528-34.

10 Bishop N. Bone disease in preterm infants. Arch Dis Child 1989; 64: 1403-9.

11 Cooper PA, Rothberg AD, Davies VA, Argent AC. Comparative growth and biochemical response of very low birthweight infants fed own mothers' milk, a premature infant formula, or one of two standard formulas mature infant formula, or one of two standard
$\mathcal{F}$ Pediatr Gastroenterol Nutr 1985; 4: 786-94.

12 Houchang DMN, Lim MO, Hansen JW, Sickles V. Growth, biochemical status, and mineral metabolism in very-low-birthweight infants receiving fortified preterm human milk. F Pediatr Gastroenterol Nutr 1986; 5: 762-7.

13 Chan GM, Mileur L, Hansen JW. Effects of increased calcium and phosphorus formulas and human milk on bone mineralisation in preterm infants. $\mathcal{F}$ Pediatr Gastroenterol Nutr 1986; 5: 444-9.

14 Lucas A, Bishop NJ, Ling FJ, Cole TJ. Randomised trial of nutrition for preterm infants after discharge. Arch Dis nutrition for preterm

15 Steichen JJ, Keriakes JG, Tsang RC. Radiation dose to small infants from single-photon absorptiometry. Radiology 1988; 168: 169-70.

16 Prentice AM, Laskey MA, Shaw J, Cole TJ, Fraser DR. Bone mineral content of Gambian and British children aged 0-36 months. Bone Miner 1990; 10: 211-24.

17 Congdon PJ, Horsman A, Ryan SW, Truscott JG, Durward $\mathrm{H}$. Spontaneous resolution of bone mineral depletion in preterm infants. Arch Dis Child 1990; 65: 1038-42.

18 Chan GM, Mileur LJ. Posthospitalisation growth and bone mineral status of normal preterm infants. Am $7 \mathrm{Dis}$ Child 1985; 139: 896-8.

19 Schanler RJ, Burns PA, Abrams SA, Garza C. Bone mineralization outcomes in human milk-fed preterm infants. Pediatr Res 1992; 31: 583-6.

20 Wahner HW, Dunn WL, Riggs BL. Assessment of bone mineral Part 2. F Nucl Med 1984; 25: 1241-53.

21 Larcos G, Wahner HW. An evaluation of forearm bone mineral measurement with dual energy $x$-ray absorptiometry. F Nucl Med 1991; 32: 2101-6. 
22 Chan GM, Hess M, Hollis J, Book LS. Bone mineral content in accidental childhood fractures. Am 7 Dis Child 1984; 138: 569-70.

23 Landin L, Nilsson BE. Bone mineral content in children with fractures. Clin Orthop 1983; 183: 292-6.

24 Dahlenburg SL, Bishop NJ, Lucas A. Are preterm infants at risk for subsequent fractures? Arch Dis Child 1989; 64: risk for

25 Bonjour JP, Theintz G, Buchs B, Slosman D, Rizzoli R. Critical years and stages of puberty for spinal and femoral bone mass accumulation during adolescence. $₹$ Clin Endocrinol Metab 1991; 73: 555-63.
26 Gilsanz V, Roe TF, Mora S, Costin G, Goodman WG. Changes in vertebral bone density in black girls and white girls during childhood and puberty. $N$ Engl f Med 1991; 325: $1597-600$.

27 Glastre C, Braillon P, David L, Cochat P, Meunier PJ, Delmas PD. Measurement of bone mineral content of the lumbar spine by dual $x$-ray absorptiometry in normal children: correlations with growth parameters. $\mathfrak{f} \mathrm{Clin}$ Endocrinol Metab 1990; 70: 1330-3.

28 Helin I, Landin L, Nilsson BE. Bone mineral content in preterm infants at age 4 to 16. Acta Paediatr Scand 1985; 74: $264-7$.

不 